\title{
Application of pumpkin seed powder in sponge cakes
}

\section{Zhivka Goranova ${ }^{1}$, Todorka Petrova1, ${ }^{1}$ van Bakalov¹, Marianna Baeva²}

\author{
1 - Institute of Food Preservation and Quality, Plovdiv, Bulgaria \\ 2 - University of Food Technology, Plovdiv, Bulgaria
}

\begin{abstract}
In this study, the physical, color and sensory properties of sponge cake supplemented with two different levels of pumpkin seed powder (0, 5 and 10\%) were evaluated. Sensory evaluation of sponge cakes with pumpkin seed powder revealed very high consumer acceptance. In this studying the volume of the cakes with pumpkin seed powder was smaller than this of cake control $(255.00 \pm 5.07$ $\mathrm{cm}^{3}$ ) as the volume of the cake with $5 \%$ pumpkin seed powder had the smallest volume $\left(229.00 \pm 5.17 \mathrm{~cm}^{3}\right)$. The greatest porosity was observed in the cake control $(65.62 \pm 1.41 \%)$ and cake with $5 \%$ pumpkin seed powder $(64.20 \pm 1.00 \%)$. The water-absorbing capacity of the cake control $(312.60 \pm 3.15 \%)$ is the lowest than that of the cakes with 5 and $10 \%$ pumpkin seed powder. The lowest values for chroma were detected at the crust for the cake containing $10 \%$ pumpkin seed powder as fiber source. The color of crust and crumb on the control was similar to that of the cake with $5 \%$ pumpkin seed powder.
\end{abstract}

Key words: sponge, cake, pumpkin, seed.

Corresponding author: Zhivka Goranova

E-mail: jivka_goranova@abv.bg

DOI: $10.24263 / \mathrm{RES}-2019-8$

\section{Introduction}

Now-a-days, consumers are much more concerned about their health and demand the food products conferring health benefits with reduced calories, low sugar content, high protein and dietary fiber. Consumers also look for the products that are more natural-like.

Pumpkin belongs to the family Cucurbitaceae and is widely grown vegetable all over the world. Pumpkin processing into puree, juice, candied fruit and pumpkin seed oil results in large amount of by-products. Pumpkins are rich in carotenoids, vitamins, minerals, pectin and dietary fibre. Pumpkin seed has received considerable attention in recent years because of the nutritional and health protective values of the seeds. The seed is an excellent source of protein and also has pharmacological activities such as anti-diabetic, antifungal, antibacterial, anti-inflammation activities and antioxidant effects. Besides, the pumpkin is economical and a nutrient dense source, the pumpkin seed. flour fortified complementary food mix is economical, with highly acceptable 
sensory qualities and a rich nutritive value, quoted that, pumpkin seeds offer a nutritious, sweet, somewhat soft and chewy snack or food additive [1]. They also have omega 3 \& omega 6 fatty acids needed for hormone balance, brain function and skin health. Tryptophan present in these seeds aids in milk production in lactating mothers and used to reduce postpartum swelling of the hands and feet. Hence Pumpkin seeds serve as a good nutritious snack and helps in promoting good health. Pumpkin seeds have one of the highest levels of antioxidants of any nut, seed or food [2]. Fresh seeds of Cucurbita moschata contain moisture, $28.5 \%$; protein, $37.7 \%$; and ash, $4.4 \%$; where as, dried pumpkin seeds contain moisture content of $5.6 \%$, protein content of $37.4 \%$ and ash content of 4.4\% [1]. Pumpkin seeds are reported to be a excellent source of Bcomplex vitamins, proteins and also has pharamacological activities such as antidiabetic, antifungal, antibacterial and anti-inflammation and antioxidant. Pumpkin seeds are rich in exogenous amino acids (e.g. lysine, thyrosine, tryptophan, methionine) and in iron $(96 \pm 33 \mathrm{ppm})$, thus being recommendable to children and adolescents often prone to iron deficiencycaused anaemia [3]. The addition of pumpkin seed flour to this product, conducted to an increased of the total essential amino acids, protein, fat and mineral content, showing that the pumpkin seed flour is a good source of protein and nutrients for bread fortification [4]. All those specificities of pumpkin seed flour make it a potentially valuable additive to sponge cakes.

This study had investigated the effects of the addition of pumpkin seed powder on the physical, color and sensory characteristics of sponge cakes.

\section{Materials and methods}

Cake preparation. Materials for production of sponge cakes were wheat flour, sugar, eggs, defatted pumpkin seed powder from local market. The control cake was prepared, following a traditional technology and formulation [5]. The batter formulation of the control cake was as follows (based on flour weight): egg yolk $43.23 \%$, egg white $96.77 \%$, granulated sugar $83.87 \%$, and wheat flour $100 \%$. In particular, a double mixing procedure was applied by partitioning whipping of whites and egg yolks. Defatted pumpkin seed powder was added into sponge cake flour at different levels 0,5 and 10\%, by replacing wheat flour, respectively. Each sponge cakes batter of $95 \mathrm{~g}$ was poured out into metallic forms and baked in an electric oven at $180^{\circ} \mathrm{C}$ for $30 \mathrm{~min}$. The sponge cakes were stored at standard conditions (at temperature of $18^{\circ} \mathrm{C}$ and $75 \%$ relative humidity). The humidity and the temperature were kept constant by means of a desiccator supplied with psychrometer, and put in a thermostat with accuracy of $\pm 0.5^{\circ} \mathrm{C}$.

Physical characteristics. The specific gravity of the sponge cake was calculated by dividing the weight of a standard batter cup with the weight of an equal volume of distilled water, at batter temperature $\left(20.8 \pm 0.5^{\circ} \mathrm{C}\right)$ [6]. The physical characteristics of the sponge cakes were determined $2 \mathrm{~h}$ after baking. Volume was measured by the small 
uniform seed displacement method [7], and and porosity was assessed according to the Bulgarian State Standard method [8]. The porosity of sponge cake was defined as the ratio between the volume of the air-pockets in the cake crumb and the volume of the crumb. The porosity determination was performed using a cylinder driller. The specific volume was expressed as the ratio of the sponge cake volume to its mass. The waterabsorbing capacity of the sponge cake was measured by the extent of biscuit swelling according to the Bulgarian State Standard method [9].

Color characteristics of sponge cakes. The instrumental measurement of the cakes color was carried out with a colorimeter Color-guide 45/0 Colorimeter, BYKGardner Inc, USA, and the results were expressed in accordance with the CIELAB system. Color was measured at four predetermined places of the sponge cakes crust and crumb. The parameters determined were $\mathrm{L}^{*}\left(\mathrm{~L}^{*}=0\right.$ [black] and $\mathrm{L}^{*}=100$ [white]), $a^{*}\left(-a^{*}=\right.$ greenness and $+a^{*}=$ redness $), b^{*}\left(-b^{*}=\right.$ blueness and $+b^{*}=$ yellowness $)$. Colorimeters give measurements that can be correlated with human eye-brain perception, and give tristimulus $\left(\mathrm{L}^{*}, \mathrm{a}^{*}\right.$ and $\left.\mathrm{b}^{*}\right)$ values directly.

Chroma, $\mathrm{C}^{*}$, is the aspect of color in by which a sample appears to difference from a gray of the same lightness or brightness, as defined by the following equations:

$\mathrm{C}^{*}=\sqrt{\mathrm{a}} \mathrm{a}^{2}+\mathrm{b}^{* 2}$

The total color difference $\left(\Delta \mathrm{E}^{*}\right)$ between the control cake and the sponge cakes with functional ingredients was calculated as follows:

$\Delta \mathrm{E}^{*}=\sqrt{ }\left(\Delta \mathrm{L}^{*}\right)^{2}+\left(\Delta \mathrm{a}^{*}\right)^{2}+\left(\Delta \mathrm{b}^{*}\right)^{2}$,

as: $\Delta \mathrm{L}^{*}=\mathrm{L}_{1}-\mathrm{L}_{0} ; \Delta \mathrm{a}^{*}=\mathrm{a}_{1}-\mathrm{a}_{0} ; \Delta \mathrm{b}^{*}=\mathrm{b}_{1}-\mathrm{b}_{0}$.

The values used to determine if the total color difference was visually obvious were the following.

$\Delta \mathrm{E}^{*}<1$ color differences are not obvious for the human eye;

$1<\Delta \mathrm{E}^{*}<3$ color differences are not appreciative by the human eye;

$\Delta \mathrm{E}^{*}>3$ color differences are obvious for the human eye [10-11].

Sensory characteristics. The descriptive test for a quantitative sensory profiling was used to establish the sensory characteristics (shape, color, cell size and uniformity, odour, sweetness, aftertaste, crumb tenderness) of the sponge cakes, $6 \mathrm{~h}$ after baking, following the ISO 8586:2014 and ISO 13299:2016 methods [12-13]. The sponge cakes samples were ready $1 \mathrm{~h}$ before the evaluation. Samples of different cakes were kept in coded plates covered with aluminium foil. Twelve trained panelists were selected to guarantee the evaluation accuracy. The intensity of each sensory characteristic was recorded on a ten-point linear scale after $1 \mathrm{~h}$ orientation sessions of the panelists, where they specified terminology and anchor points on the scale. The coded samples were shown simultaneously and evaluated in random order among the panelists. 


\section{Results and discussion}

The developed recipe composition of sponge cakes with an additive of pumpkin seeds was prepared by the replacement of wheat flour with defatted pumpkin seed powder in quantity $5 \%$ and $10 \%$. The recipe compositions of the control sample and the investigated cakes containing an additive of defatted pumpkin seed powder are presented in Table 1.

Tab le 1

Sponge cake batters formulations

\begin{tabular}{|c|c|c|c|}
\hline \multirow{3}{*}{ Ingredients } & \multicolumn{3}{|c|}{ Amount based on: } \\
\hline & \multirow{2}{*}{$\begin{array}{c}\text { Flour weight } \\
{[\%]} \\
\text { Control } \\
\text { sample }\end{array}$} & \multicolumn{2}{|c|}{$\begin{array}{l}\text { Flour mix (wheat flour and defatted pumpkin } \\
\text { seed powder) weight [\%] }\end{array}$} \\
\hline & & $\begin{array}{c}\text { With 5\% defatted } \\
\text { pumpkin seed powder }\end{array}$ & $\begin{array}{c}\text { With } 10 \% \text { defatted } \\
\text { pumpkin seed powder }\end{array}$ \\
\hline Yolk of egg & 43.23 & 43.23 & 43.23 \\
\hline White of egg & 96.77 & 96.77 & 96.77 \\
\hline $\begin{array}{l}\text { Refined granulated } \\
\text { sugar }\end{array}$ & 83.87 & 83.87 & 83.87 \\
\hline $\begin{array}{l}\text { Wheat flour type } \\
500\end{array}$ & 100.00 & 95.00 & 90.00 \\
\hline $\begin{array}{l}\text { Defatted pumpkin } \\
\text { seed powder }\end{array}$ & - & 5.00 & 10.00 \\
\hline
\end{tabular}

The stages of technology were kept because of their easy fulfillment and the considerably small duration of the technological cycle. The sponge cakes containing defatted pumpkin seed powder were processed at constant regime of baking concurrent with that of the control sample, which according to the technological instruction was baked for $30 \mathrm{~min}$ at $180{ }^{\circ} \mathrm{C}$.

The addition of pumpkin seeds powder in sponge cakes improves their physical characteristics (Table 2). Specific gravity in cake batter provides an indication of the total air holding capacity of the batter. Low specific gravity values indicate good incorporation of air, yielding a higher final volume after baking; however, many other factors also affect this quality parameter. The difference in respect the specific volume between the control cake-sample and the sponge cakes with pumpkin seed powder is minimal. In this studying the volume of the cakes with pumpkin seed powder was smaller than this of cake control $\left(255.00 \pm 5.07 \mathrm{~cm}^{3}\right)$ as the volume of the cake with $5 \%$ pumpkin seed powder had the smallest volume $\left(229.00 \pm 5.17 \mathrm{~cm}^{3}\right)$. The greatest porosity was observed in the cake control $(65.62 \pm 1.41 \%)$ and cake with $5 \%$ pumpkin seed powder $(64.20 \pm 1.00 \%)$. The water-absorbing capacity of the cake control $(312.60 \pm 3.15 \%)$ is the lowest than that of the cakes with 5 and $10 \%$ pumpkin seed powder. 
Resource and Energy Saving Technologies of Production and Packing of Food Products as the Main Fundamentals of Their Competitiveness: Proceedings of the 8th International Specialized Scientific and Practical Conference, September 12, 2019. Kyiv, Ukraine

Table 2

Physical characteristics of the sponge batters and cakes

\begin{tabular}{|l|c|c|c|}
\hline \multirow{2}{*}{ Physical characteristics } & \multicolumn{3}{|c|}{ Sponge cake types } \\
\cline { 2 - 4 } & Control sample & $\begin{array}{c}\text { with 5\% } \\
\text { pumpkin seed } \\
\text { powder }\end{array}$ & $\begin{array}{c}\text { with 10\% } \\
\text { pumpkin seed } \\
\text { powder }\end{array}$ \\
\hline $\begin{array}{l}\text { Specific gravity (for } \\
\text { batter) }\end{array}$ & $0.75 \pm 0.04^{\mathrm{c}}$ & $0.79 \pm 0.02^{\mathrm{d}}$ & $0.80 \pm 0.01^{\mathrm{d}}$ \\
\hline Volume, $\mathrm{cm}^{3}$ & $255.00 \pm 5.07^{\mathrm{c}}$ & $229.00 \pm 5.17^{\mathrm{d}}$ & $235.00 \pm 7.95^{\mathrm{d}}$ \\
\hline Specific volume, $\mathrm{cm}^{3} / \mathrm{g}$ & $3.56 \pm 0.11^{\mathrm{c}}$ & $3.40 \pm 0.21^{\mathrm{c}}$ & $3.17 \pm 0.09^{\mathrm{d}}$ \\
\hline Porosity,\% & $65.62 \pm 1.41^{\mathrm{c}}$ & $64.20 \pm 1.00^{\mathrm{c}}$ & $63.88 \pm 1.03^{\mathrm{cd}}$ \\
\hline $\begin{array}{l}\text { Water-absorbing } \\
\text { capacity,\% }\end{array}$ & $312.60 \pm 3.15^{\mathrm{c}}$ & $317.20 \pm 3.07^{\mathrm{d}}$ & $321.37 \pm 4.00^{\mathrm{d}}$ \\
\hline
\end{tabular}

${ }^{\mathrm{a}}$ The values are mean $\pm \mathrm{SD}(\mathrm{p}<0.05)$.

${ }^{\mathbf{b}}$ The temperature of the batter is on the average $20.7 \pm 0.5^{\circ} \mathrm{C}$.

c-d The values in a line with identical letters do not different statistical significantly $(\mathrm{p}<0.05)$.

\section{Color characteristics of sponge cakes}

Measurements of color properties for the tested compositions of sponge cakes with functional components were conducted on crust and crumb of fresh cakes (Figure 1 and Figure 2).

Crust color of cakes. The lightest samples (highest $\mathrm{L}^{*}$ values) were control cake (56.21 \pm 2.23$)$ present in Figure 1. The control and cake with with 5\% pumpkin seed powder have the highest values of $b^{*}$ (yellow component) indicating a significantly brighter and more saturated yellow color. The lightness, $a^{*}$ and $b^{*}$ values for control were not significantly different from those of the cake with pumpkin seed powder. The control cakes had the highest value of chroma of crust. The lowest values for chroma were detected at the crust for the cake containing 10\% pumpkin seed powder as fibre source. According to these results, cakes with functional component - pumpkin seed powder where the $\Delta \mathrm{E}^{*}$ was appreciable by the human eye $\left(\Delta \mathrm{E}^{*}>3\right)$.

Crumb color of cakes. The variations in the crumb color of the cakes with functional components as flour replacer were similar to the variations in crust color (Figure 2). The cake with with 5\% pumpkin seed powder was the lightest and the $b^{*}$ values showed that this sample had a brighter color. The crumb color on the control sample was similar to that of the cake with einkorn wholemeal flour. The lowest values for chroma were detected at the crumb for the cake containing 5\% pumpkin seed powder. According to these results, cakes with $10 \%$ pumpkin seed powder where the $\Delta \mathrm{E}^{*}$ was appreciable by the human eye. 
Resource and Energy Saving Technologies of Production and Packing of Food Products as the Main Fundamentals of Their Competitiveness: Proceedings of the 8th International Specialized Scientific and Practical Conference, September 12, 2019. Kyiv, Ukraine

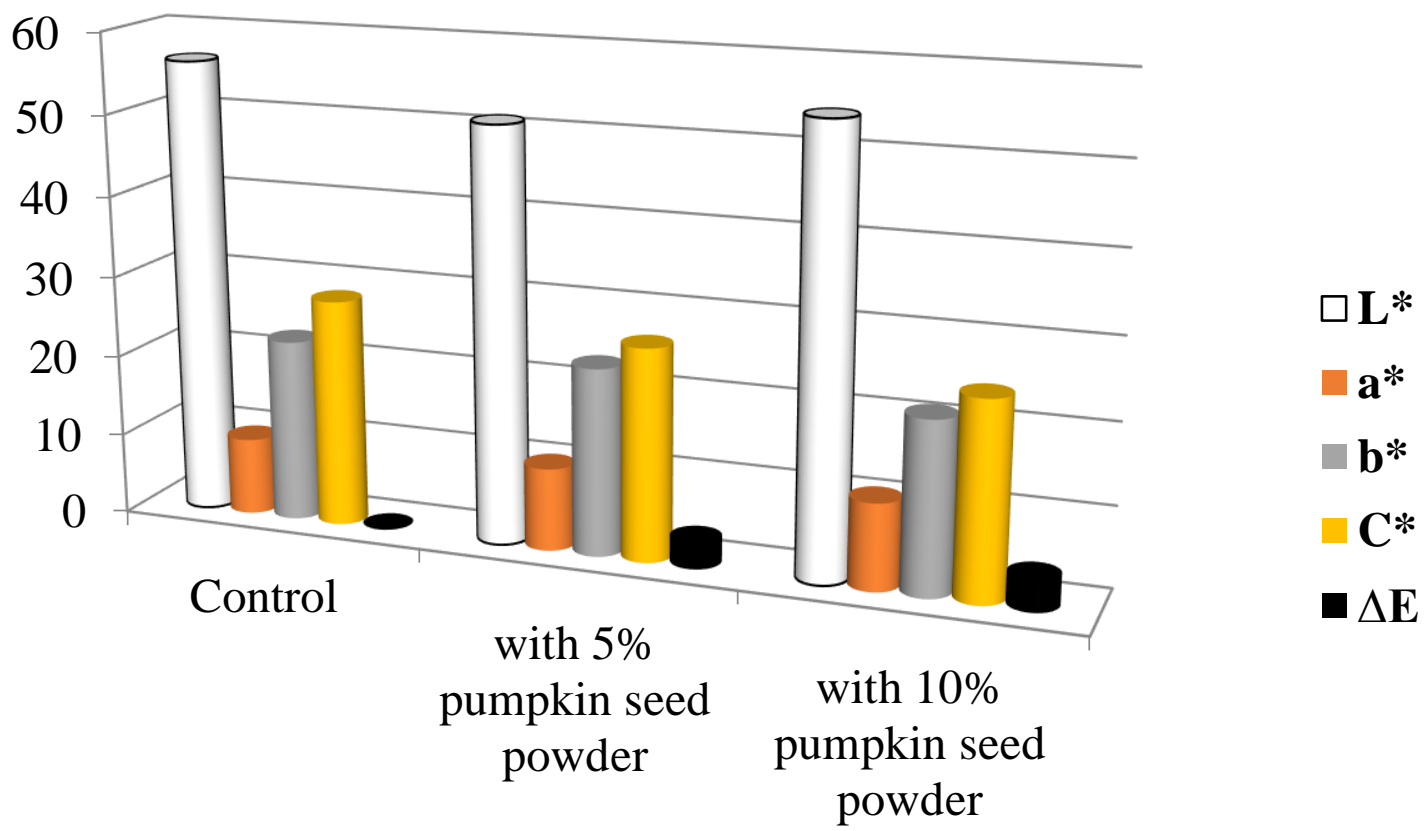

Type of sponge cake

Figure 1. Crust color values of sponge cakes

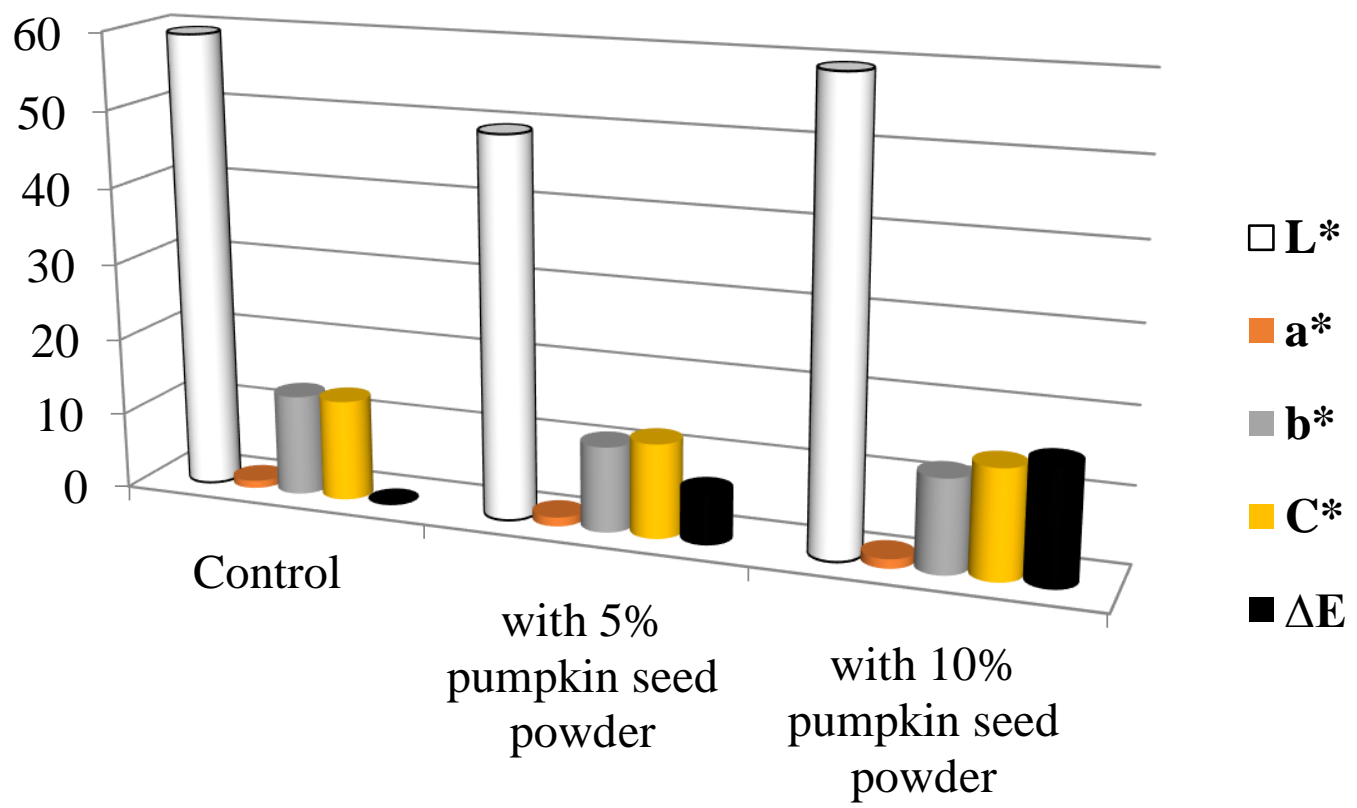

Type of sponge cake

Figure 2. Crumb color values of sponge cakes 


\section{Sensory evaluation}

Taste is the primary factor in determining the acceptability of any product and has the highest impact in determining the market success of product.

The sponge cakes containing an additive of pumpkin seed powder have good sensory characteristics present in Table 3 . The sensory analysis demonstrates that the structure is fine-porous in all kinds of investigated sponge cakes. The control cake and the cakes with pumpkin seeds have approximately similar form. The crumb pores of cakes with pumpkin seeds in the investigated three kinds of cakes are with thicker walls, small and equal in size. The odour of the cakes with pumpkin seeds is perceived as more pleasant than the control cake-sample one. The color of the cakes with pumpkin seeds is perceived well from the testers. The intensity of the sweetness for all investigated sponge cakes is close, but when the concentration of the pumpkin seed is greater a bitter aftertaste is read.

Sensory characteristics of the sponge cakes

Table 3

\begin{tabular}{|l|c|c|c|}
\hline \multirow{2}{*}{\begin{tabular}{c}
\multirow{2}{*}{$\begin{array}{c}\text { Sensory } \\
\text { characteristics }\end{array}$} \\
\cline { 2 - 4 }
\end{tabular}} & \multicolumn{3}{|c|}{ Sponge sucrose-sweetened cake type } \\
\hline Shape & $8.58 \pm 0.26^{\mathrm{c}}$ & $\begin{array}{l}\text { Control sample } \\
\text { powder }\end{array}$ & $\begin{array}{l}\text { 10\% pumpkin seed } \\
\text { powder }\end{array}$ \\
\hline Color & $8.00 \pm 0.74^{\mathrm{c}}$ & $6.42 \pm 1.07^{\mathrm{d}}$ & $8.04 \pm 0.75^{\mathrm{d}}$ \\
\hline $\begin{array}{l}\text { Cells size and } \\
\text { uniformity }\end{array}$ & $8.42 \pm 1.02^{\mathrm{c}}$ & $7.46 \pm 1.16^{\mathrm{d}}$ & $7.79 \pm 1.02^{\mathrm{d}}$ \\
\hline Odour & $7.52 \pm 1.19^{\mathrm{c}}$ & $7.78 \pm 2.40^{\mathrm{d}}$ & $7.66 \pm 2.07^{\mathrm{d}}$ \\
\hline Sweetness & $6.07 \pm 1.08^{\mathrm{c}}$ & $5.54 \pm 1.26^{\mathrm{d}}$ & $5.77 \pm 1.35^{\mathrm{d}}$ \\
\hline Aftertaste & $2.46 \pm 2.48^{\mathrm{c}}$ & $1.62 \pm 1.99^{\mathrm{d}}$ & $1.83 \pm 1.92^{\mathrm{d}}$ \\
\hline Crumb tenderness & $8.51 \pm 0.75^{\mathrm{c}}$ & $8.32 \pm 1.65^{\mathrm{d}}$ & $8.15 \pm 1.56^{\mathrm{d}}$ \\
\hline
\end{tabular}

a The values are mean \pm SD $(\mathrm{p}<0.05)$.

${ }^{\mathbf{b}} \mathrm{A}$ scale from 0 to 9 was used to evaluate sensory characteristics. Nine is ideal for the third sensory characteristic when the cells are small and equal in size.

c-d The values in a line with identical letters do not differ statistical significantly $(\mathrm{p}<0.05)$.

It was observed that the higher crumb tenderness scores for control resulted an increase in the overall liking values. The all cakes have similar shape (Table 5). The crumb pore cells of the cake with 5\% pumpkin seed powder had thicker walls, and they were larger and equal in size. The cells of the sponge cake-control were smaller and almost uniformly distributed in the crumb, with thinner walls. The cake-control had a crust and crumb with more pronounced light-yellow colour due to the presence of the color components in the yolks of the egg (carotenoids). The colour of the crust and crumb of the cakes with 5\% and 10\% pumpkin seed powder are light-brown with lightgreen nuance. The odour of the all cakes is perceived by the sensory panelists as pleasant. The intensity of the sweetness for all investigated sponge cakes is close. 


\section{Conclusions}

This study investigated the potentials of pumpkin by-products in sponge cake production. The physical and sensory characteristics of the sponge cakes with 5\% and $10 \%$ pumpkin seed powder are juxtaposed with those of the control sample. The color on the control was similar to that of the cake with $5 \%$ pumpkin seed powder. The lightness, $a^{*}$ and $b^{*}$ values for crust control were not significantly different from those of the cake with 5\% pumpkin seed powder. The crumb color on the control sample was similar to that of the cake with pumpkin seed powder. According to these results, cakes with $10 \%$ pumpkin seed powder where the $\Delta \mathrm{E}^{*}$ was appreciable by the human eye. On the grounds of this we consider that newly prepared products have good qualitative characteristics, and they are suitable as intermediate products in confectioneries designed for rational and functional nutrition.

\section{References}

1. Saraswathi D., Renu R., Maloo S. (2018), Development and quality evaluation of pumpkin seeds and flaxseeds powder incorporated biscuits, International Journal of Food Science and Nutrition, 3(2), pp. 78-83.

2. Revathy M.N, Sabitha N. (2013), Development, quality evaluation and pupularization of pumpkin seed flour incorporated bakery products. International Journal of Food Nutrition Science, 2, pp.40-41.

3. Dhiman A., Bavita K., Attri S \& Ramachandran P. (2018). Preparation of pumpkin powder and pumpkin seed kernel powder for supplementation in weaning mix and cookies. International Journal of Chemical Studies, 6(5), pp. 167-175.

4. Codină G. \& Mironeasa, S. (2016), Application of d-optimal mixture design to optimize the wheat-pumpkin composite flour for bread production. Journal of Faculty of Food Engineering, XV(1), pp. 10-20.

5. Angelov L., Bekirov B., Genadieva M., Atanasov S. (1974), OH 146 200-72. In Handbook of branch standards, rates of consumption and technological instructions in confectionaryture, I, pp. 176-183.

6. AACC (American Association of Cereal Chemists) (1983), Approved methods of the AACC. Method 10-95. 8th ed. St. Paul, Minn, USA: AACC International

7. AACC. (2000), Method 10-05.01. Guidelines for measurement of volume by rapeseed displacement. Approved method of the American Association of Cereal Chemists, International. Approved Methods of Analysis, 11th edition. St. Paul, $\mathrm{MN}$ : AACC International

8. Bulgarian State Standard (1979), Method 3412-79. Retrieved on 01 September 2019 from http://www. bds-bg.org/bg/standard/?natstandard_document_id=13099

9. BSS. (1981). Method for determination of water absorption ability of the biscuits. Bulgarian State Standard, 15221-81. 
Resource and Energy Saving Technologies of Production and Packing of Food Products as the Main Fundamentals of Their Competitiveness: Proceedings of the 8th International Specialized Scientific and Practical Conference, September 12, 2019. Kyiv, Ukraine

10. Baixauli R., Salvador A. \& Fiszman S. M. (2008), Textural and colour changes during storage and sensory shelf life of muffins containing resistant starch, European Food Research and Technology, 226, pp. 523-530.

11. Popov-Raljić J. V. \& Laličić-Petronijević J. G. (2009), Sensory properties and color measurements of dietary chocolates with different compositions during storage for up to 360 days, Sensors 2009, 9 (3), 1996-2016; doi:10.3390/s90301996

12. ISO 8586:2014 (2014), Sensory analysis - General guidelines for the selection, training and monitoring of selected assessors and expert sensory assessors.

13. ISO 13299:2016 (2016), Sensory analysis - Methodology - General guidance for establishing a sensory profile. 